\title{
PENTINGNYA PEMBERIAN ASI EKSKLUSIF PADA BAYI DI POSYANDU BUNGA TANJUNG DESA TANAH MERAH
}

\author{
Eliya Mursyida ${ }^{1}$, Ratih Ayuningtiyas ${ }^{2}$, Nurmaliza Hasan ${ }^{3}$ \\ Program Studi Pendidikan Dokter, Universitas Abdurrab, Jl. Riau Ujung No. 73 \\ email: eliya_mursyida@univrab.ac.id
}

\begin{abstract}
ABSTRAK
Air Susu Ibu (ASI) merupakan makanan alami yang memiliki nilai nutrisi yang sangat ideal dengan komposisi yang seimbang dan sesuai dengan kebutuhan bagi pertumbuhan atau perkembangan bayi. ASI Eksklusif menurut World Health Organization (WHO) dan United Nations Children's Fund (UNICEF) adalah ASI yang diberikan kepada bayi usia 0-6 bulan pertama tanpa tambahan cairan ataupun makanan lain. ASI banyak memberikan manfaat bagi bayi maupun ibu. Bagi bayi salah satunya dapat mencegah bayi dari berbagai penyakit, sedangkan bagi ibu dapat mencegah terjadinya kanker payudara. Tujuan dari pengabdian ini adalah memberi informasi atau pengetahuan kepada masyarakat tentang pentingnya pemberian ASI Eksklusif pada bayi di Posyandu Bunga Tanjung. Kegiatan pengabdian masyarakat dilaksanakan di Posyandu Bunga Tanjung menggunakan metode oral atau presentasi kepada masyarakat. Sebanyak 20 responden (100\%), diperoleh $90 \%$ responden yang memiliki pengetahuan dengan kategori baik. Sosialisasi tentang ASI Eksklusif merupakan wujud dalam pemberian informasi kepada setiap ibu yang memiliki bayi maupun calon ibu.
\end{abstract}

Kata kunci: ASI Eksklusif, Kandungan ASI, Manfaat ASI, Pengetahuan, Posyandu Bunga Tanjung

\begin{abstract}
Mother's Milk (ASI) is a natural food that has nutritional value that is ideal with a balanced composition and in accordance with the needs for growth or development of the baby. Exclusive breastfeeding according to the World Health Organization (WHO) and the United Nations Children's Fund (UNICEF) is breast milk given to infants aged 0-6 months without additional fluids or other foods. ASI provides many benefits for babies and mothers. For babies, one of them can prevent babies from various diseases, while for mothers can prevent breast cancer. The purpose of this service is to provide information or knowledge to the public about the importance of exclusive breastfeeding for babies in Posyandu Bunga Tanjung. Community service activities are carried out at Posyandu Bunga Tanjung using oral methods or presentations to the community. A total of 20 respondents (100\%), obtained $90 \%$ of respondents who have good category knowledge. The dissemination of Exclusive Breastfeeding is a form of providing information to very mother who has a baby or prospective mother.
\end{abstract}

Key words: exclusive breastfeeding, the content of breast milk, the benefits of breast milk, knowledge, Posyandu Bunga Tanjung 


\section{PENDAHULUAN}

Air Susu Ibu (ASI) merupakan makanan alami yang memiliki nilai nutrisi yang sangat ideal dengan komposisi yang seimbang dan sesuai dengan kebutuhan bagi pertumbuhan atau perkembangan bayi (Roesli 2000; Suririnah 2009). ASI Eksklusif menurut World Health Organization (WHO) dan United Nations Children's Fund (UNICEF) adalah ASI yang diberikan kepada bayi usia 0-6 bulan pertama tanpa tambahan cairan ataupun makanan lain.

ASI banyak memberikan manfaat bagi bayi maupun ibu. Bagi bayi salah satunya dapat mencegah bayi dari berbagai penyakit, sedangkan bagi ibu dapat mencegah terjadinya kanker payudara. Beberapa penelitian mengenai pemberian ASI menunjukkan bahwa ASI dapat mencegah timbulnya penyakit. Menurut Wijayanti (2010) bayi dengan pemberian ASI Eksklusif memiliki angka kejadian diare lebih rendah dibandingkan bayi yang tidak mendapatkan ASI Eksklusif.

Berdasarkan Profil Kesehatan Riau Tahun 2015, persentase pemberian ASI Eksklusif pada bayi 0-6 bulan di Provinsi Riau pada tahun 2015 sebesar 68,8\% (Dinkes Pekanbaru 2015). Capaian ini lebih tinggi dibandingkan dengan tahun 2014 sebesar 52,4\%. Meskipun capaian ini terus meningkat, persentase pemberian ASI Eksklusif pada bayi belum mencapai target nasional yaitu $80 \%$. Sebanyak 12 Kabupaten/Kota di Provinsi Riau belum ada Kabupaten/Kota yang mencapai target nasional. Pada gambar 1 berikut dapat dilihat cakupan ASI Eksklusif di Provinsi Riau tahun 2015.

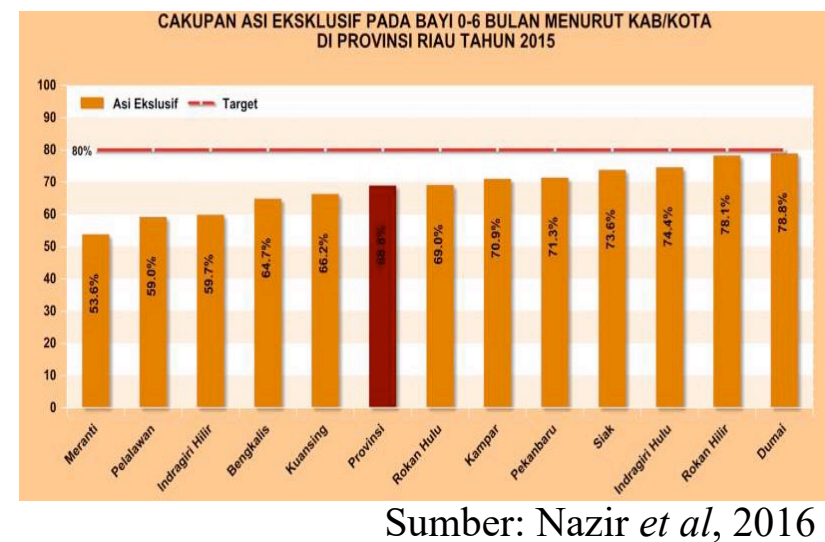

Gambar 1. Cakupan ASI Eksklusif di Provinsi Riau

Posyandu merupakan salah satu bentuk Upaya Kesehatan Bersumberdaya Masyarakat (UKBM) yang dikelola dari, oleh, untuk, dan bersama masyarakat, guna memberdayakan masyarakat dan memberikan kemudahan kepada masyarakat dalam memperoleh pelayanan kesehatan dasar (Kemenkes 2012).

Posyandu Bunga Tanjung (Gambar 2) merupakan Posyandu yang terletak di Desa Tanah Merah Kecamatan Siak Hulu Kabupaten Kampar yang rutin melakukan pelayanan kesehatan dasar terutama untuk kesehatan ibu dan anak. Demi meningkatkan cakupan ASI Eksklusif pada bayi usia 0-6 bulan, perlu peningkatan sosialisasi kepada masyarakat akan pentingnya manfaat pemberian ASI terhadap tumbuh kembang balita dan kesehatan Ibu. Oleh karena itu, dari latar belakang di atas maka dilakukan pengabdian kepada masyarakat tentang pentingnya pemberian ASI Eksklusif pada bayi di Posyandu Bunga Tanjung Desa Tanah Merah. Tujuan dari pengabdian ini adalah memberi informasi atau pengetahuan kepada masyarakat tentang pentingnya pemberian ASI Eksklusif pada bayi. Urgensi pengabdian, diharapkan masyarakat, terutama wanita 
usia subur, ibu-ibu yang memiliki bayi usia 0-24 bulan, serta ibu hamil dapat memberikan ASI kepada anaknya.

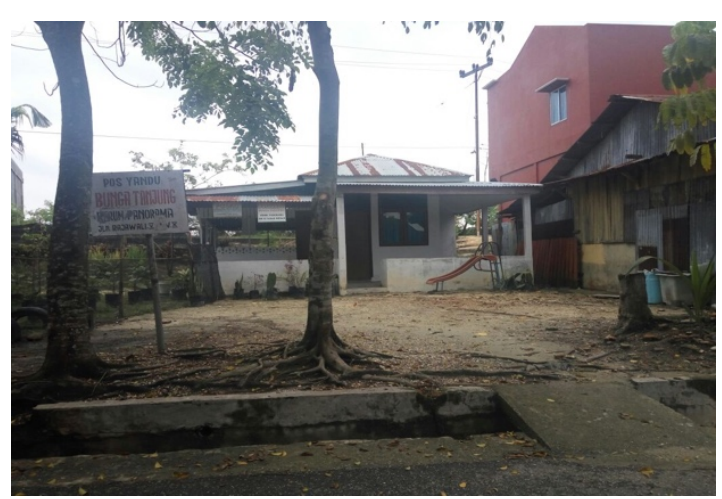

Gambar 2. Posyandu Bunga Tanjung

\section{TINJAUAN PUSTAKA}

Menurut Roesli (2000), ASI merupakan suatu emulsi lemak dalam larutan protein, laktosa, dan garam-garam anorganik yang disekresikan oleh kelenjar mamae ibu. ASI mampu memenuhi semua unsur kebutuhan bayi, karena mengandung berbagai nutrisi, dan sebagainya. Komposisi ASI setiap orang berbeda-beda, baik itu dari satu periode laktasi ke periode lain, dan bahkan setiap jam dalam sehari. ASI sendiri mengandung antara lain, nutrisi, lemak, karbohidrat, garam mineral, air, vitamin seperti kolostrum, hormon, antialergi, antiinflamasi (Coad dan Dunstall 2006; Purwanti 2004). Menurut Departemen Kesehatan (2005), kolostrum mengandung zat kekebalan, vitamin A yang tinggi, serta lebih kental dan berwarna kekuning-kuningan. Pada saat yang sama ASI juga kaya akan sari-sari makanan yang mempercepat pertumbuhan sel-sel otak dan perkembangan sistem saraf (Yahya 2009).

ASI memiliki manfaat yang baik bagi bayi antara lain, sebagai sumber nutrisi, dapat meningkatkan daya tahan tubuh karena ASI mengandung zat antibodi seperti immunoglobin, lisozim, laktoferin, komplemen $\mathrm{C}_{3}$ dan $\mathrm{C}_{4}$, dapat meningkatkan kecerdasan bayi, serta dapat meningkatkan jalinan kasih sayang ibu dan anak (Roesli 2000; Gupte 2004). Selain itu, ASI juga memberikan manfaat bagi ibu, antara lain dapat mempererat hubungan antara ibu dan anak, serta perkembangan psikis dan emosional antara ibu dan anak, mengurangi kemungkinan terjadinya kanker payudara pada masa yang akan datang, dapat menyebabkan pengembalian rahim keukuran sebelum hamil, mempercepat berhentinya pendarahan post partum dan pastinya lebih praktis, ekonomis, murah, menghemat waktu dan memberi kepuasan pada ibu (Gupte 2004).

Adapun beberapa faktor yang dapat mempengaruhi produksi ASI, antara lain: (1) makanan ibu, ibu yang sedang menyusui harus mendapat tambahan makanan agar tidak terjadi penurunan produksi ASI, (2) ketentraman jiwa dan pikiran, (3) perawatan payudara, (4) penggunaan alat kontrasepsi, (5) keberadaan perokok pasif (Siregar 2004; Safitri 2016). Selain itu, ada juga beberapa faktor yang mempengaruhi ketidakberhasilan ASI yaitu (1) faktor internal (pengetahuan, pendidikan, pekerjaan, kelainan payudara, Inisiasi Menyusui Dini (IMD), dan kondisi kesehatan ibu) dan (2) faktor eksternal (faktor petugas kesehatan, kondisi kesehatan bayi, pengganti ASI atau susu formula, keyakinan) (Purnamasari 2015). 


\title{
METODE PELAKSANAAN \\ Waktu dan Tempat
}

Kegiatan pengabdian kepada masyarakat dilakukan pada bulan Mei 2018 di Posyandu Bunga Tanjung Desa Tanah Merah.

\section{Langkah-Langkah Kegiatan}

Adapun langkah-langkah kegiatan yang dilakukan adalah sebagai berikut:

1. Pembuatan materi sosialisasi dan leaflet untuk meningkatkan pengetahuan masyarakat tentang pentingnya pemberian ASI Eksklusif pada bayi.

2. Menjalin kerjasama dengan kader Posyandu Bunga Tanjung untuk mengadakan sosialisasi kepada masyarakat.

3. Pemberian materi sosialisasi kepada masyarakat tentang pentingnya ASI Eksklusif.

4. Penyebaran kuesioner setelah sosialisasi untuk melihat tingkat pengetahuan masyarakat tentang pentingnya ASI Eksklusif.

\section{Teknik Penyelesaian Masalah}

Teknik penyelesaian masalah dilakukan dengan menggunakan metode oral atau presentasi kepada masyarakat, disertai sesi Tanya jawab.

\begin{abstract}
Alat Ukur Ketercapaian
Demi menilai ketercapaian pelaksanaan pengabdian kepada masyarakat yang dilaksanakan, maka dilakukan observasi menggunakan kuesioner. Hasil yang diperoleh dari kuesioner yang telah diisi oleh masyarakat sesudah pemberian sosialisasi, selanjutnya dianalisis. Penilaian kuesioner yaitu, nilai 1 diberikan untuk jawaban benar dan nilai 0 untuk jawaban salah, lalu digolongkan menjadi 3 kategori, yaitu baik, sedang, kurang. Dikatakan baik $(>80 \%)$, cukup $(60-80 \%)$, dan kurang $(<60 \%)$ (Khomsan 2000).
\end{abstract}

\section{HASIL DAN PEMBAHASAN}

Masyarakat sasaran yang hadir dalam sosialisasi tentang pentingnya pemberian ASI Eksklusif pada bayi di Posyandu Bunga Tanjung, diikuti oleh sebanyak 20 orang ibu dengan usia, pendidikan terakhir, pekerjaan, serta jumlah anak yang berbeda-beda (Tabel 1).

Posyandu Bunga Tanjung merupakan posyandu yang aktif dalam mengadakan kegiatan pemeriksaan kesehatan bagi anak usia di bawah $<2$ tahun atau lebih, dan juga bagi ibu. Berdasarkan karakteristik tersebut, maka dilakukan pengabdian kepada masyarakat di Posyandu Bunga Tanjung guna memberi informasi mengenai tentang pentingnya pemberian ASI Eksklusif kepada bayi, serta manfaatnya bagi ibu.

Hasil yang didapatkan dari penyebaran kuesioner pengetahuan ibu terhadap pentingnya ASI Eksklusif, diketahui sebanyak 90\% dari responden sudah memiliki pengetahuan yang baik mengenai pentingnya ASI Eksklusif. Hal ini dapat dilihat dari sangat antusiasnya masyarakat dengan materi yang disampaikan pemateri yang disertai dengan tanya jawab diakhir pemaparan (Gambar 3). Selain itu, pengetahuan seorang ibu juga merupakan salah satu faktor dari ketidakberhasilannya pemberian ASI Eksklusif pada bayi. Hal ini sesuai dengan Roesli (2005), jika tingkat pendidikan ibu rendah maka pengetahuan ibu tentang ASI juga rendah sehingga pemberian ASI Eksklusif selama 6 bulan tidak akan tercapai. 
Demi mempertahankan tingkat pengetahuan yang sudah baik ini, maka perlu diadakan kegiatan rutin untuk memperkuat pengetahuan masyarakat yang sudah ada. Penguatan ini dapat dilakukan secara mandiri oleh pihak posyandu melalui kader-kader yang sudah dilatih oleh pihak Puskesmas maupun bekerja sama dengan instansi-instansi kesehatan lainnya, seperti Program Studi Pendidikan Dokter, Kebidanan, Keperawatan, dan lainnya.

Tabel 1. Karakteristik Masyarakat Sasaran

\begin{tabular}{|c|c|c|c|c|}
\hline No & Usia & Pendidikan & Pekerjaan & $\begin{array}{c}\text { Jumlah } \\
\text { anak }\end{array}$ \\
\hline 1 & 32 & SMA & IRT & 2 \\
\hline 2 & 26 & SMA & IRT & 1 \\
\hline 3 & 35 & SMA & IRT & 3 \\
\hline 4 & 33 & S1 & IRT & 2 \\
\hline 5 & 33 & SMA & IRT & 2 \\
\hline 6 & 38 & SMA & IRT & 5 \\
\hline 7 & 27 & SLTP & Wiraswasta & 3 \\
\hline 8 & 35 & SMA & IRT & 3 \\
\hline 9 & 36 & S1 & Guru Paud & 2 \\
\hline 10 & 56 & SMA & IRT & 3 \\
\hline 11 & 44 & SMA & Wiraswasta & 3 \\
\hline 12 & 34 & SMA & IRT & 2 \\
\hline 13 & 38 & S1 & IRT & 2 \\
\hline 14 & 40 & SLTP & IRT & 3 \\
\hline 15 & 32 & SMA & IRT & 4 \\
\hline 16 & 36 & SMA & IRT & 2 \\
\hline 17 & 38 & SMA & IRT & 3 \\
\hline 18 & 28 & S1 & IRT & 2 \\
\hline 19 & 45 & SMA & IRT & 1 \\
\hline 20 & 30 & SMA & IRT & 3 \\
\hline
\end{tabular}

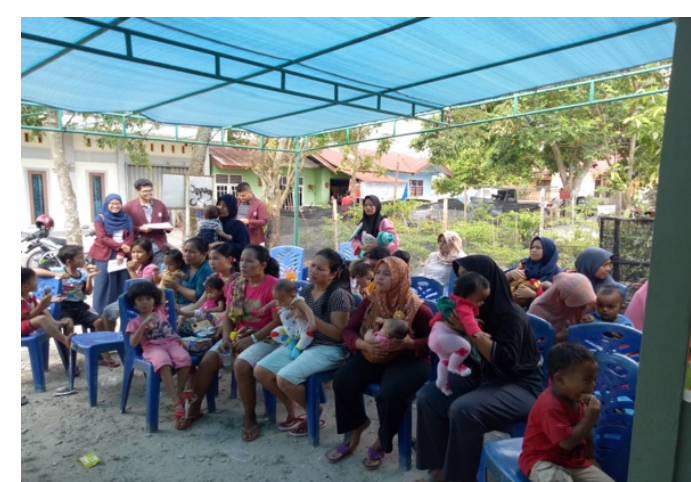

Gambar 3. Peserta Kegiatan Sosialisasi Pentingnya ASI Eksklusif Pada Bayi

\section{KESIMPULAN}

Sebanyak 20 responden (100\%), diperoleh sebanyak 90\% responden yang memiliki pengetahuan dengan kategori baik. Sosialisasi tentang ASI Eksklusif merupakan wujud dalam pemberian informasi kepada setiap ibu yang memiliki bayi maupun calon ibu. 
Walaupun pembahasan tentang ASI Eksklusif telah banyak didengar, alangkah lebih baik lagi jika sering mengikuti sosialisasi tentang pemberian ASI Eksklusif kepada msyarakat khususnya Desa Tanah Merah, agar masyarakat lebih memahami tentang manfaat ASI bagi ibu maupun bayi.

Terima kasih kepada LPPM Universitas Abdurrab melalui hibah pengabdian kepada masyarakat, serta masyarakat dan kader-kader di Posyandu Bunga Tanjung yang sudah berpartisipasi dalam kegiatan ini.

\section{DAFTAR PUSTAKA}

[5]. Coad J, Dunstall M. 2006. Anatomi dan Fisiologi untuk Bidan. Jakarta. EGC

[6]. Depkes RI. 2005. Manajemen Laktasi. Jakarta. Kemenkes RI

[7]. Dinkes KP. 2015. Profil Kesehatan Kota Pekanbaru Tahun 2015. http://www.depkes.go.id/resources/download/profil/PROFIL_KAB_KOTA_201 5/1471_Riau_Kota_Pekanbaru_2015.pdf [02 Februari 2018]

[8]. Gupte S. 2004. Panduan Perawatan Anak. Jakarta. Yayasan Obor Indonesia

[9]. Kemenkes RI. 2012. Pusat Promosi Kesehatan Tahun 2012. http://www.depkes.go.id/resources/download/promosi-kesehatan/buku-sakuposyandu.pdf [02 Februari 2018]

[10]. Khomsan A. 2000. Teknik Pengukuran Pengetahuan Gizi. Bogor. Jurusan Gizi Masyarakat dan Sumber Daya Keluarga Fakultas Pertanian Institut Pertanian Bogor

[11]. Nazir MY, Munir R, Jajuli A. 2016. Profil Kesehatan Provinsi Riau 2016. Pekanbaru. Dinas Kesehatan Provinsi Riau

[12]. Purnamasari D. 2015. Faktor-faktor yang Berhubungan dengan Ketidakberhasilan ASI Eksklusif di Wilayah Kerja Puskesmas Pakualaman Kota Yogyakarta. Yogyakarta. STIKES ’Aisyiyah Yogyakarta

[13]. Purwanti HS. 2004. Konsep Penerapan ASI Eksklusif: Buku Saku untuk Bidan. Jakarta. EGC

[14]. Roesli U. 2000. Mengenal ASI Eksklusif. Jakarta. Tubulus Agriwidya

[15]. Roesli U. 2005. Panduan Praktis Menyusui. Jakarta. Puspa Swara

[16]. Safitri I. 2016. Faktor-faktor yang Mempengaruhi Kelancaran Produksi ASI pada Ibu Menyusui di Desa Bendan, Kecamatan Banyudono, Kabupaten Boyolali. Surakarta. Universitas Muhammadiyah Surakarta

[17]. Siregar MA. 2004. Pemberian ASI Ekslusif dan Faktor-Faktor yang Mempengaruhinya. Medan. USU digital library

[18]. Suririnah. 2009. Buku Pintar Merawat Bayi 0-12 bulan. Jakarta. Gramedia Pustaka Utama

[19]. Wijayanti W. 2010. Hubungan Antara Pemberian ASI Eksklusif dengan Angka Kejadian Diare pada Bayi Umur 0-6 bulan di Puskesmas Gilingan Kecamatan Banjarsari Surakarta. [2018]

[20]. Yahya H. 2009. Cairan Ajaib ASI. Jakarta. Elex Media Komputindo 